\title{
DEVELOPMENT AND VALIDATION OF ULTRAVIOLET SPECTROPHOTOMETRIC METHOD FOR QUANTITATIVE ESTIMATION OF FAMOTIDINE IN BULK AND TABLET DOSAGE FORM
}

\author{
RITESH KUMAR ${ }^{1 *}$, AMRISH CHANDRA ${ }^{2}$, PAWAN KUMAR GAUTAM ${ }^{3}$ \\ ${ }^{1}$ Department of Pharmacy, IFTM University, Moradabad - 244 102, Uttar Pradesh, India. ${ }^{2}$ Department of Pharmacy, Amity Institute of \\ Pharmacy, Amity University, Noida - 201 313, Uttar Pradesh, India. ${ }^{3}$ Department of Pharmacy, S. N. Medical College, Agra - 282002 , Uttar \\ Pradesh, India. Email: ritesh_pharma@rediffmail.com
}

Received: 13 May 2017, Revised and Accepted: 28 June 2017

\section{ABSTRACT}

Objectives: The purpose of the study is to develop a simple, precise, economical, accurate, reproducible, and sensitive method for the estimation of famotidine (FAM) in bulk and its pharmaceutical dosage forms by ultraviolet (UV) absorption spectrophotometry.

Methods: The method uses $0.1 \mathrm{~N} \mathrm{HCl}, \mathrm{pH} 1.20$ as a solvent for the quantitative estimation of FAM in bulk and its tablets dosage form by UV absorption spectrophotometry.

Results: FAM exhibited absorbance maxima at $266 \mathrm{~nm}$ in $0.1 \mathrm{~N} \mathrm{HCl}$ pH 1.20 solvent. The developed method was validated as per the ICH analytical method validation guidelines. Beer's law was obeyed in range of $0-30 \mu \mathrm{g} / \mathrm{ml}$ with $\mathrm{r}^{2}=0.9998$. The limit of detection and limit of quantification values of FAM were found to be 0.152 and $0.461 \mu \mathrm{g} / \mathrm{ml}$, respectively. The mean percentage recovery for developed method was found to be in the range of 99.35-99.48\%, respectively, for the marketed dosage forms. The developed method was also found to be robust and ensures bench-top stability.

Conclusion: The developed method was found to be suitable for the routine quantitative analysis of FAM in bulk and pharmaceutical dosage form. It was also concluded that developed UV spectrophotometry method was accurate, precise, linear, reproducible, robust, and sensitive.

Keywords: Famotidine, Ultraviolet spectrophotometry, Validation, Assay, Beer's law.

(C) 2017 The Authors. Published by Innovare Academic Sciences Pvt Ltd. This is an open access article under the CC BY license (http://creativecommons. org/licenses/by/4. 0/) DOI: http://dx.doi.org/10.22159/ajpcr.2017.v10i8.19902

\section{INTRODUCTION}

Famotidine (FAM) (Fig. 1) known as 3-([2-(diamino-methyleneamino) thiazol-4-yl] methylthio)- $\mathrm{N}^{\prime}$-sulfamoylpropanimidamide. FAM is a potent histamine $\mathrm{H}_{2}$-receptor antagonist used in the treatment of duodenal ulcer, peptic ulcer, Zollinger-Ellison syndrome, and gastroesophageal reflux disease [1]. FAM has short biological halflife ( 2.5-4 hrs) with site-specific absorption in the upper part of the gastrointestinal tract (GIT) with oral bioavailability of $43-50 \%$ due to the narrow absorption window in GIT and is also stable in gastric $\mathrm{pH}$. Therefore, development and validation of a method for the estimation of FAM in $0.1 \mathrm{~N} \mathrm{HCl}, \mathrm{pH} 1.20$ (SGF) would be an ideal approach for FAM. The empirical formula and molecular weight of FAM are $\mathrm{C}_{8} \mathrm{H}_{15} \mathrm{~N}_{7} \mathrm{O}_{2} \mathrm{~S}_{3}$ and $337.445 \mathrm{~g}$, respectively. Histamine is a chemical present mostly in the storage granules of mast cells of the body that causes production of acid in the stomach. $\mathrm{H}_{2}$-blockers inhibit histamine action and therefore reduce gastric secretion of acid produced [2].

The literature survey revealed that various methods of analysis for FAM have been reported which includes titrimetry, high-performance liquid chromatography, high-performance thin-layer chromatography, spectrophotometric, spectrofluorimetric flow injection analysis, potentiometry, polarography, etc. [3-10].

Some of these methods have enough sensitivity to determine lower concentrations of drug; however, many of these techniques are deficient in simplicity, cost-effectiveness, and accessibility. Out of these, ultraviolet (UV) spectrophotometry or spectroscopy method is characterized by its speed, simplicity, accuracy, and inexpensiveness. An UV-spectroscopic method has been reported for FAM in $0.1 \mathrm{~N} \mathrm{HCl}$, pH 1.20 (SFG) solvent and validated according to ICH norms [11].

\section{METHODS}

Instrumentation

A double-beam UV-visible spectrophotometer 1800, Shimadzu, software version 2.23 using $1 \mathrm{~cm}$ matched quartz cell with a slit width of $1 \mathrm{~mm}$ was used for all the spectral and absorbance measurements. The scanning speed was kept medium. Electronic weighing balance (Shimadzu analytical balance) was used for weighing purpose.

Reagents and chemicals

Pure drug sample of FAM was supplied as a gift sample by Sun Pharmaceutical Industry, Dadar, India. Sample was used without further purification. Tablets used for analysis were procured from local pharmacy. All chemicals and reagents were of analytical grade, and double-distilled water was used throughout the investigation to develop spectral characteristics.

\section{Selection of solvent}

$0.1 \mathrm{~N} \mathrm{HCl}, \mathrm{pH} 1.20$ was selected as a solvent to study the spectral characteristics of FAM. It was prepared according to the Indian Pharmacopoeia 2014.

\section{Preparation of standard stock solution}

Accurately weighed $10 \mathrm{mg}$ pure drug sample of FAM was transferred to $100 \mathrm{ml}(100 \mu \mathrm{g} / \mathrm{ml})$ calibrated volumetric flask, dissolved, and made up to the mark with $0.1 \mathrm{~N} \mathrm{HCl}, \mathrm{pH} 1.20$. It was the stock solution of FAM $(100 \mu \mathrm{g} / \mathrm{ml})$ in $0.1 \mathrm{~N} \mathrm{HCl}, \mathrm{pH} 1.20$.

Using the stock solution of $100 \mu \mathrm{g} / \mathrm{ml}$, subsequently dilution was carried out by withdrawing different aliquots $(0.5,1.0,1.5,2.0,2.5$, $3.0 \mathrm{ml}$ ) from standard solution were transferred into a series of $10 \mathrm{ml}$ calibrated volumetric flasks and all were made up to the mark with 
$0.1 \mathrm{~N} \mathrm{HCl}, \mathrm{pH} 1.20$ to prepare working standard solutions of different concentrations $(5-30 \mu \mathrm{g} / \mathrm{ml})$.

\section{Selection of detection wavelength}

Solution of FAM in concentration of $10 \mu \mathrm{g} / \mathrm{ml}$ was scanned in the range of wavelength 200-400 nm [12]. It was observed that the FAM showed considerable absorbance at wavelength of $266 \mathrm{~nm}$. The absorption spectrum was found to be sharp and maximum at wavelength of $266 \mathrm{~nm}$, therefore, it was selected as the wavelength for detection in $0.1 \mathrm{~N} \mathrm{HCl}$, pH 1.20 (Fig. 2).

\section{Preparation of calibration curve}

Solution of FAM in $0.1 \mathrm{~N} \mathrm{HCl}, \mathrm{pH} 1.20$ in different concentrations $(5,10$, $15,20,25$, and $30 \mu \mathrm{g} / \mathrm{ml}$ ) was taken, and absorbance of these solutions was measured against solvent $0.1 \mathrm{~N} \mathrm{HCl}, \mathrm{pH} 1.20$ as blank at wavelength of $266 \mathrm{~nm}$. A calibration curve was plotted from the absorbance values so obtained $[13,14]$. From the calibration curve, it was found that FAM obeys Beer's law in concentrations of $5-30 \mu \mathrm{g} / \mathrm{ml}$.

\section{Preparation of sample solution}

Ten tablets of FAM (Famocid 20) were weighed accurately and powdered finely. An accurately weighed quantity of tablets powder equivalent to $100 \mathrm{mg}$ of FAM was transferred to a $100 \mathrm{ml}$ volumetric flask and diluted with $0.1 \mathrm{~N} \mathrm{HCl}, \mathrm{pH} 1.20$, and the content was ultrasonicated for 20 minutes. The volume was made up to the mark with solvent and mixed well. The solutions were further filtered using Whatman No. 1 filter paper to remove any unwanted particulate matters. The filtered solutions were further appropriately diluted with respective solvent to finally produce sample solution of concentration $10 \mu \mathrm{g} / \mathrm{ml}$ for analysis. The amount of FAM present in the sample solution was determined using the calibration curve of standard drug.

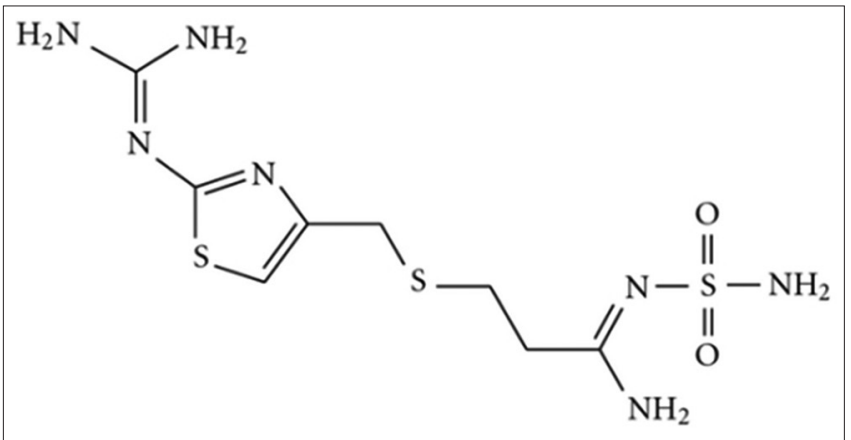

Fig. 1: Structure of famotidine

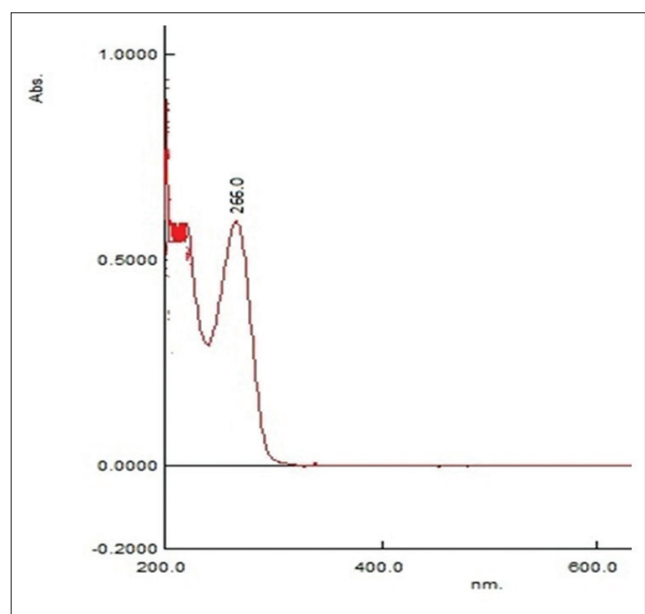

Fig. 2: Ultraviolet spectra of famotidine in $0.1 \mathrm{~N} \mathrm{HCl} \mathrm{(pH} \mathrm{1.20)}$

\section{Method validation of developed method}

The method was validated according to the ICH Q2 (R1) guidelines for parameters such as linearity, range, precision, limit of detection (LOD), limit of quantification (LOQ), accuracy, recovery, and stability of the analyte.

\section{Linearity and range}

The linearity of the analytical method was its ability to elicit test results which are directly proportional to analyte concentration in samples within a given range. Range was determined to know the interval between the upper and lower concentrations of analyte (pure FAM) that had been demonstrated to determine that the analytical method with a suitable level of precision, accuracy, and linearity [15]

To establish the linearity and range of the proposed method, various aliquot portions of $0.5-3 \mathrm{ml}$ of FAM stock solution $(100 \mu \mathrm{g} / \mathrm{ml})$ was separately transferred into $10.0 \mathrm{ml}$ volumetric flask and diluted up to the mark with mobile phase $(0.1 \mathrm{~N} \mathrm{HCl}, \mathrm{pH} 1.20)$ to obtain final concentrations of 5-30 $\mu \mathrm{g} / \mathrm{ml}$, respectively. The absorbance at each concentration was measured against solvent $0.1 \mathrm{~N} \mathrm{HCl}, \mathrm{pH} 1.20$ as blank at a wavelength of $266 \mathrm{~nm}$. Calibration curve was constructed by plotting absorbance of FAM (nm) on Y-axis and concentration of FAM $(\mu \mathrm{g} / \mathrm{ml})$ on X-axis and regression equation was calculated for the drug.

\section{Precision}

Precision studies were carried out to ascertain the reproducibility of results for the proposed method and used to find out intra- and inter-day variations in the test method of FAM. It was determined by repeatability [16]. Repeatability was determined by preparing three replicates of same concentration of the sample and the absorbance was measured. Intraday precision study was carried out by preparing drug solution of same concentrations $(5,10$, and $20 \mu \mathrm{g} / \mathrm{ml}$ ) and analyzing it at three different times in a day. The same procedure was followed for three other days to determine interday precision. The results were reported as \% relative standard deviation (RSD).

\section{LOD and LOQ}

LOD is the lowest amount of analyte in the study or test sample that can be detected. LOQ is the lowest amount of analyte in the study or test sample that can be quantitatively determined by suitable precision and accuracy. LOD and LOQ were determined using the following equations designated by the ICH guidelines [17].

LOD $-3.3 \mathrm{~s} / \mathrm{m}$

$\mathrm{LOQ}-10 \mathrm{~s} / \mathrm{m}$

Where, $\mathrm{s}$ is the standard deviation of the response and $\mathrm{m}$ is the slope of the related calibration curve.

\section{Accuracy study}

Accuracy study was carried out to assure the closeness of the test results obtained by the analytical method to the true value [18]. For study methods, samples were prepared in triplicate at three different concentrations, that is, 10,15 , and $20 \mu \mathrm{g} / \mathrm{ml}$ within the Beer's law limits and absorbance of each concentration was recorded in triplicate $(n=3)$. The results were reported as standard deviation and \% RSD.

\section{Recovery study}

Recovery study was carried out to check accuracy of the proposed method by addition of standard drug solution topre-analyzed tablet dosage form of FAM sample solution at three different concentration levels $(75 \%, 100 \%$, and $125 \%)$ within the specified linearity and range. The basic concentration level of sample solution selected for spiking of the drugs standard solution was $10 \mu \mathrm{g} / \mathrm{ml}$ of FAM for the used method. The percentage recovery by proposed method was calculated using the formula as below. 
Where accuracy given in:

Percentage relative error $=[($ Estimated concentration - Total concentration)/Total concentration] $\times 100$

E: Total amount of drug estimated $(\mu \mathrm{g} / \mathrm{ml})$,

$\mathrm{T}$ : Amount of drug taken from pre-analyzed tablet dosage form $(\mu \mathrm{g} / \mathrm{ml})$,

P: Amount of pure drug added $(\mu \mathrm{g} / \mathrm{ml})$.

\section{Stability study}

Stability experiments were performed to evaluate the short-term FAM solution stability under different conditions. Experiments were performed to determine the stability of bench top (20 hrs). The sample was found stable if \% deviations are $<1 \%$.

\section{Robustness}

Robustness was carried out by analyzing FAM concentration on different days by different analysts. This study was useful to predict the effect of various parameters such as different laboratories, different analysts, interday and intraday variations [19-21].

\section{Assay of marketed formulations of FAM}

The average weight of 10 tablets of marketed brand of FAM was accurately calculated, and these tablets were crushed well into a uniform powder. Calculated weight of powdered drug was taken to prepare $100 \mu \mathrm{g} / \mathrm{ml}$ stock solution. Three replicates of the test solution of

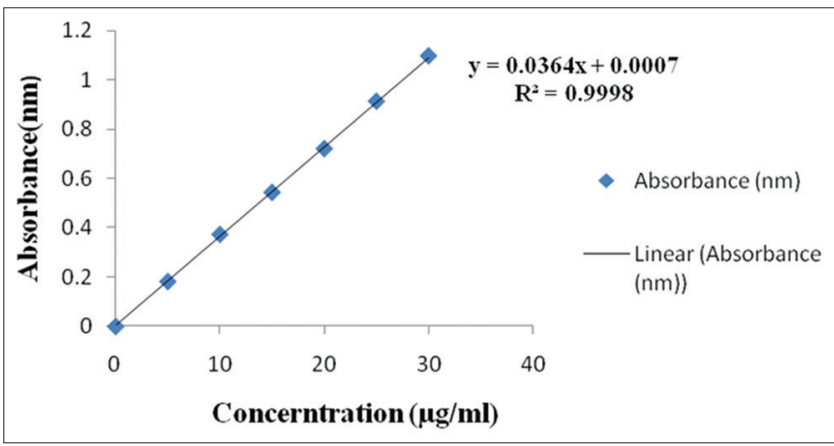

Fig. 3: Calibration curve of famotidine

Table 1: Various parameters of developed methods of FAM

\begin{tabular}{ll}
\hline Parameter & Result \\
\hline Absorption maxima & $266 \mathrm{~nm}$ \\
Beer's law range & $0-30 \mu \mathrm{g} / \mathrm{ml}$ \\
Correlation coefficient & 0.99989 \\
Regression coefficient & 0.9998 \\
Regression equation & $\mathrm{y}=0.0007 \pm 0.0364 \mathrm{x}$ \\
Slope & 0.0364 \\
Intercept & 0.0007 \\
SD & 0.00168 \\
$\mathrm{LOD}, \mu \mathrm{g} / \mathrm{ml}$ & 0.152 \\
$\mathrm{LOQ}, \mu \mathrm{g} / \mathrm{ml}$ & 0.461 \\
\hline
\end{tabular}

SD: Standard deviation, LOD: Limit of detection, LOQ: Limit of quantification, FAM: Famotidine
$10 \mu \mathrm{g} / \mathrm{ml}$ were prepared from dilution of stock solution and sonicated. The amounts of FAM were calculated by extrapolating the absorbance from the calibration plot. Results of analysis are reported in Table 7.

\section{RESULTS AND DISCUSSION}

\section{Linearity and range}

The absorbance of FAM at each concentration of $5-30 \mu \mathrm{g} / \mathrm{ml}$ was measured against solvent $0.1 \mathrm{~N} \mathrm{HCl}, \mathrm{pH} 1.20$ as blank at wavelength of $266 \mathrm{~nm}$. Calibration curve was constructed by plotting absorbance versus concentrations, and regression equation was calculated for drug. The equation of calibration curve for FAM obtained was $y=0.0007+0.0364 x$, good linearity was observed over the concentration range evaluated $(5-30 \mu \mathrm{g} / \mathrm{ml})$ with regression coefficient $\left(\mathrm{r}^{2}\right)=0.9998$ are shown in Fig. 3. The calibration curve was found to be linear for the proposed spectrophotometric method in the aforementioned concentrations $(5-30 \mu \mathrm{g} / \mathrm{ml})$. The linear regression data for the calibration plot are indicative of a good linear relationship between peak area and concentration over wide range (Table 1).

\section{Precision}

In the intraday study, concentration of drug was calculated on the same day at an interval of $2 \mathrm{hrs}$. In interday study, the concentration of drug contents was calculated on three different days within laboratory variation. In both intraday and interday precision, the study was expressed as RSD of a set of results. The precision of the method (\% RSD) of FAM for intraday and interday was found to be $<1 \%$ in each concentration showing good repeatability. The values of percentage RSD for both intraday and interday precision are shown in Table 2 .

\section{LOD and LOQ}

The LOD and LOQ of FAM by proposed method were determined using standard deviation method with calibration standards. The LOD and LOQ of the proposed method were found to be 0.152 and $0.461 \mu \mathrm{g} / \mathrm{ml}$, respectively, indicating that the method developed is sensitive and without interference of the excipients.

\section{Accuracy study}

Accuracy of the method was determined and results of the study showed low value of percentage RSD indicating an accurate method (Table 3) as well as non-interference with the excipients of the formulation.

\section{Recovery study}

To perform the accuracy of the developed method and to study the interference of formulation additives, analytical recovery experiments were carried out by standard addition method. All value come under $100 \pm 1 \%$ (Table 4 ) that indicate method is accurate

\section{Stability study}

The sample was subjected for short-term stability studies under room temperature. The solution was stable for up to $20 \mathrm{hrs}$. The sample was found bench-top stable with $\%$ RSD $<1$ as shown in Table 5 .

\section{Robustness}

Robustness study showed non-significant difference in the amount of drug recovery ( $\%$ assay) in different laboratory, analyst, and variations condition. Robustness study suggested that developed method was

Table 2: Determination of intraday and interday precision for three different concentrations of FAM

\begin{tabular}{|c|c|c|c|c|c|}
\hline \multirow[t]{2}{*}{ S.No. } & \multirow[t]{2}{*}{ Normal concentration $(\mu \mathrm{g} / \mathrm{ml})$} & \multicolumn{2}{|l|}{ Intraday precision $(n=3)$} & \multicolumn{2}{|l|}{ Interday precision $(n=3)$} \\
\hline & & $\begin{array}{l}\text { Concentration measured } \\
(\mu \mathrm{g} / \mathrm{ml})(\text { Mean } \pm \mathrm{SD})\end{array}$ & $\%$ RSD & $\begin{array}{l}\text { Concentration measured } \\
(\mu \mathrm{g} / \mathrm{ml})(\text { Mean } \pm \mathrm{SD})\end{array}$ & $\%$ RSD \\
\hline 1 & 5 & $4.94 \pm 0.047$ & 0.96 & $4.95 \pm 0.30$ & 0.62 \\
\hline 2 & 10 & $9.98 \pm 0.30$ & 0.31 & $9.97 \pm 0.025$ & 0.25 \\
\hline 3 & 20 & $19.94 \pm 0.08$ & 0.40 & $19.94 \pm 0.065$ & 0.33 \\
\hline
\end{tabular}


Table 3: Accuracy data for three different concentrations of FAM for the developed method

\begin{tabular}{llll}
\hline S.No. & Concentration $(\mu \mathrm{g} / \mathrm{ml})$ & $\begin{array}{l}\text { Absorbance } \\
\text { measured }(\mathrm{Mean} \pm \mathbf{S D})\end{array}$ & \% RSD \\
\hline 1 & 5 & $0.183 \pm 0.0019$ & 1.03 \\
2 & 10 & $0.374 \pm 0.0031$ & 0.82 \\
3 & 20 & $0.721 \pm 0.0047$ & 0.65 \\
\hline
\end{tabular}

SD: Standard deviation, FAM: Famotidine, RSD: Relative standard deviation

Table 4: Result of recovery study by percentage recovery method

\begin{tabular}{|c|c|c|c|c|}
\hline Marketed dosage form & Content of drug (mg) & Level of addition (\%) & $\%$ Recovery $\pm \%$ RSD $(n=3)$ & $\%$ Mean recovery $\pm \%$ RSD \\
\hline \multirow[t]{3}{*}{ Facid 20 tablet } & 20 & 75 & $99.72 \pm 0.47$ & \multirow[t]{3}{*}{$99.48 \pm 0.42$} \\
\hline & 20 & 100 & $99.52 \pm 0.25$ & \\
\hline & 20 & 125 & $99.65 \pm 0.54$ & \\
\hline \multirow[t]{3}{*}{ Famocid 20 tablet } & 20 & 75 & $99.24 \pm 0.75$ & \multirow[t]{3}{*}{$99.35 \pm 0.71$} \\
\hline & 20 & 100 & $99.38 \pm 0.58$ & \\
\hline & 20 & 125 & $99.43 \pm 0.82$ & \\
\hline
\end{tabular}

RSD: Relative standard deviation

Table 5: Result of short-term stability (bench top) study

\begin{tabular}{llllll}
\hline S.No. & $\begin{array}{l}\text { Initial } \\
\text { concentration } \\
(\boldsymbol{\mu g} / \mathbf{m l})\end{array}$ & $\begin{array}{l}\text { Final } \\
\text { concentration } \\
\text { found }(\boldsymbol{\mu g} / \mathbf{m l})\end{array}$ & $\begin{array}{l}\text { Percent } \\
\text { deviation }\end{array}$ & SD & \% RSD \\
\hline 1 & 5 & 4.94 & 0.012 & 0.0424 & 0.85 \\
2 & 10 & 9.96 & 0.004 & 0.0282 & 0.28 \\
3 & 15 & 14.95 & 0.003 & 0.0353 & 0.24 \\
\hline \multicolumn{5}{l}{ SD: Standard deviation, RSD: Relative standard deviation }
\end{tabular}

Table 6: Data for robustness study for the developed method

\begin{tabular}{lll}
\hline S.No. & Variable parameter & Assay result (\%) \\
\hline 1 & Analyst 1 & 99.2 \\
& Analyst 2 & 99.4 \\
& Analyst 3 & 99.4 \\
2 & Day 1 & 99.7 \\
& Day 2 & 99.5 \\
& Day 3 & 99.6 \\
\hline
\end{tabular}

FAM: Famotidine

Table 7: Assay of marketed dosage form of FAM

\begin{tabular}{llll}
\hline $\begin{array}{l}\text { Marketed } \\
\text { dosage } \\
\text { form }\end{array}$ & $\begin{array}{l}\text { Label } \\
\text { claim (mg) }\end{array}$ & $\begin{array}{l}\text { Amount } \\
\text { found (mg) }\end{array}$ & $\begin{array}{l}\text { \% Purity } \\
\text { \%RSD (n=3) }\end{array}$ \\
\hline $\begin{array}{l}\text { Facid } 20 \\
\text { tablet }\end{array}$ & 20 & 19.88 & $99.40 \pm 0.45$ \\
$\begin{array}{l}\text { Fa m o cid } \\
20 \text { tablet }\end{array}$ & 20 & 19.91 & $99.55 \pm 0.68$ \\
\hline
\end{tabular}

RSD: Relative standard deviation

independent in different parameters of environmental conditions (Table 6).

\section{Assay of marketed formulations of FAM}

The assay results (\% purity) of Facid 20 and Famocid 20 tablets were found to be $99.40 \% \pm 0.45$ and $99.55 \% \pm 0.68$, respectively. The estimated content ( $\%$ purity) was in good agreement with the label claims (Table 7).

\section{CONCLUSION}

A UV-spectrophotometric method was developed and validated as per the ICH guidelines for FAM determination in bulk and pharmaceutical dosage form. The developed analytical method was found to be simple, sensitive, rapid, economical, linear, reproducible, robust, and accurate with high interday and intraday precision. The results of the validated parameters were found to be satisfactory, and therefore this method can be applied successfully for routine quality control analysis of FAM in bulk and pharmaceutical formulation.

It can also be employed for the quality control tool in estimation of FAM in pharmaceutical dosage forms. The method was found suitable to determine concentration of FAM as API or in dosage form precisely and accurately. The sample recovery from the formulation using this method was very good with respect to its label claim.

\section{ACKNOWLEDGMENT}

We are thankful to Prof. Vijay Kumar Sharma, Director, Dr. K N Modi Institute of Pharmaceutical Education and Research, Modinagar, and the management of College of Pharmacy, Agra, for providing facilities to carry out this research work.

\section{REFERENCES}

1. Reynolds EF. Martindale the Extra Pharmacoepia. $30^{\text {th }}$ ed. London: The Pharmaceutical Press; 1993. p. 884-5.

2. United States Pharmacopoeial Convention. United States Pharmacopoeia 32, National Formulary 27. Vol. 2. Rockville MD: United States Pharmacopoeial Convention; 2009. p. 2342-5.

3. Connors KA. A Textbook of Pharmaceutical Analysis. $3^{\text {rd }}$ ed. New York: Wiley Interscience Publication; 1999.

4. Mutaz A, Sheikh S, Hanan AN, Adnan BA. High pressure liquid chromatographic analysis and dissolution of famotidine in tablet formulation. Anal Lett 1989;22:2501-5.

5. Campbell AN, Sherma J. Determination of famotidine in acid reduction tablets by HPTLC and video densitometry of fluorescence quenched zones. J Liquid Chromatogr Relat Technol 2003;26:2719-22.

6. Kalsi PS. Spectroscopy of Organic Compounds. $6^{\text {th }}$ ed. New Delhi: New Age International Publishers; 2012.

7. Walash MI, Sharaf-El-Din MK, El-Sayed MM, Shabana MR. Spectrofluorimetric determination of famotidine in pharmaceutical preparations and biological fluids. Application to stability studies. J Fluoresc 2009;19:333-44

8. Tang YH, Wang NN, Xiong XY, Xiong FM, Sun SJ. A new sensitive flow-injection chemiluminescence method for the determination of H(2)-receptor antagonists. J Biolumin Chemilumin 2007;22:343-8.

9. Ayad MM, Shalaby A, Abdellatef HE, Elsaid HM. Potentiometric determination of famotidine in pharmaceutical formulations. J Pharm Biomed Anal 2002;29:247-54.

10. Ibrahim WM, Sharaf-El-Din MK, El-Sayed MM, Shabana MR Polarographic determination of famotidine through complexation with Nickel(II) Chloride. J Chin Chem Soc 2005;52:927-35.

11. ICH, Q2A. Text on Validation of Analytical Procedures. International Conference on Harmonization. Geneva: October; 1994.

12. Skoog DA, Holler FJ, Crouch SR. Instrumental Analysis. $11^{\text {th }}$ ed. Delhi: 
Cengage Learning India Pvt. Ltd.; 2012.

13. Sharma YR. Introduction of Organic Spectroscopy. $4^{\text {th }}$ ed. New Delhi: CBS Publishers and Distributors; 1991

14. Huber L. Validation of analytical methods and processes. In: The Pharmaceutical Codex: Principles and Practice of Pharmaceutics. $12^{\text {th }}$ ed. London: The Pharmaceutical Press; 1994. p. 507-24.

15. Miller JC, Miller JN. Statistics and Chemometrics for Analytical Chemistry. $5^{\text {th }}$ ed. Harlow: Pearson Education Limited; 2005.

16. Manasa P, Jaffer SK, Ashwini M, Kumar AA. A simple and a cheap UV assay method development and validation for the estimation of eplerenone in tablet. Int J Pharm Pharm Sci 2015;7:348-51.

17. ICH, Q2 (R1). Validation of Analytical Procedures: Text and Methodology, International Conference on Harmonization. Geneva: November; 2005.
18. Davidson AG. Ultraviolet-visible absorption spectrophotometry. In: Beckett AH, Stenlake JB, editors. Practical Pharmaceutical Chemistry. Part 2. $4^{\text {th }}$ ed. New Delhi: CBS Publishers and Distributors; 2002. p. 275-337.

19. Nash RA, Wachter AH, editors. Pharmaceutical Process Validation. New York: Markel Dekker, Inc.; 2008.

20. Singh S, Sharma N, Singla YP, Arora S. Development and validation of UV-spectrophotometric method for quantitative estimation of nefopam hydrochloride in polymethacrylate nanospheres. Int J Pharm Pharm Sci 2015;8(1):414-9.

21. Game MD, Sakarkar DM, Gabhane KB, Tapar KK. Validated spectrophotometric methods for the determination of cefuroxime axetil in bulk drug and tablets. Int $\mathrm{J}$ Chem Technol Res 2010;2(2):1259-62 